\title{
Farm-workers perception of personal protective equipment: Case study in the lower south coast, South Africa
}

\author{
Christopher Ugochukwu Nwafor * \\ manchrizzo@hotmail.com \\ (Dept. of Agriculture, Central University of Technology, South Africa) \\ \& \\ Ifeoma Chinyelu Nwafor \\ (Centre for Applied Food Sustainability and Biotechnology, CUT, South Africa)
}

\begin{abstract}
Safety and health issues are growing concerns in the agricultural sector among farm-workers in South Africa. The current health pandemic arising from the corona virus has thrown these issues into the spotlight, and this study explored the perceived usefulness and perceived ease of using personal protective materials among farm-workers in the banana sector. Using a case study of 10 large farms in the lower south coast of South Africa, we utilized descriptive and inferential analysis to identify the demographic composition of farm-workers in the study area, examine their perception of specific personal protective materials, and determine the relationship between demographic characteristics and perception of personal protective materials. Farm-workers in the study area were found to be predominantly single black males aged between 36-55years, with no more than a primary education, with work experience of between 6-10 years and employed as unskilled farm-labourers. Perceived usefulness (83\%) and perceived ease of use (79\%) for personal protective materials was high. Respondents gender $(p=0.012)$, marital status $(p=0.029)$, level of education $(p=0.035)$ and farm-work experience $(p=0.008)$ were significant, while their age $(p=0.057)$, population group $(p=0.160)$ and work classification $(p=0.203)$ were not found significant in determining perceived usefulness or perceived ease of use. Our study makes valuable contribution to the existing body of knowledge regarding farm-worker safety issues by exploring perception of personal protective materials.
\end{abstract}

Keywords: agriculture, farm-worker, hazard, perception, protective-materials, risks, safety

\section{Introduction}

Farm workers in South Africa are considered the most vulnerable members of the work force and also earn the lowest wages (Klaas et al., 2018). Referred to as a neglected segment in society and an almost powerless, invisible group lacking a public profile by Atkinson (2007) cited in Botes et al. (2014). The dismal socio-economic circumstances under which they live and working conditions wherein they operate has been noted by the Human Rights Watch (2011). Invariably, farm workers are vulnerable to an undue burden of social and health problems (London, 2003), since agriculture belongs to a work area classified as dangerous, dirty and demanding (Ramos et al., 2016)

The hazard-prone nature of agricultural activities is well-recognized with documented reports of the risks faced by farm-workers (Merisalu et al., 2019). According to Coman et al. (2020), these hazards also include diseases that might occur due to the nature of the work and the prevailing environment. Initiatives meant to improve the health and safety of farm workers are hence considered important, as farm-workers comprise the agricultural labour force reported by the Business and Human Rights Resource Centre (2020) to be at high risk of contracting the novel corona virus disease (covid-19) infection.

At the onset of the global corona virus pandemic characterized by national lockdowns when government emergency regulations forced a majority of the national workforce to stay at home, 
agriculture work was classified as essential (National Geographic, 2020; RSA, 2020). This classification under essential services implied that farm workers involved in different farm activities such as planting, harvesting, processing and storage activities continued to work. Various measures were put in place to reduce the risks of infection, and included physical distancing, use of hand gloves, regular hand washing with soaps and sanitizers, as well as the mandated use of face-masks. Prior to the outbreak of covid-19 in South Africa, a high prevalence of infectious diseases such as HIV and TB among farmworkers was reported. In addition to this, Landman (2011) and Herrick (2012) outlined the disastrous incidence of alcohol consumption among farm workers.

Agricultural workers especially those providing unskilled and semi-skilled services in the farm sector, are recognised as workers who have much to contribute towards sustainable agriculture, sustainable development and food security in terms of knowledge, skills and experience. The Food and Agriculture Organisation recognised them as a social group who must be empowered to tackle the poverty in which many of them live. Visser and Ferrer (2015) averred that various studies and media reports on farm workers' working and living conditions in South Africa, has enlarged the conversation regarding the complex challenges faced by agricultural workers. They identified the extensive casualization and externalisation of the farm labour force as a trending strategy aimed at coping with increased production demands, cost cutting, improvement of efficiencies, as well as avoidance of associated costs involved in managing low-skilled workers. Many of these workers also live in densely populated, sprawling underserviced informal settlements.

On a global level, several outbreaks of covid-19 infection was linked to seasonal migrant farm workers (ECDC, 2020). Possible factors contributing to covid-19 clusters in food production settings including agriculture were identified. These include working in confined or close spaces, a lack of physical distancing, shared and overcrowded accommodation, poor hygiene conditions, shared transportation, and employing seasonal workers from areas with a higher incidence of covid-19 (Summers, 2020). Farm operations especially in the banana production sector generally use some chemicals, and require workers to use personal protective clothing, such as coveralls, boots, hand gloves and face-masks. Workers also need to be trained in safety issues to protect them from the harmful effects of aerosols used for processing such as ripening and control of insects.

These operations place farm-workers in the banana production sector at risk of air-borne infections such as the novel covid-19, making the use of adequate protective clothing such as face masks highly indispensable. Traditional safety measures in the agricultural sector have relied on the duplication of best-practices, while the concerns and issues among farm workers mostly remain unexplored. Most studies about safety practices among workers have concentrated on reported or observed usage of protective materials or equipment (Afrad et al., 2020; Aguwa et al., 2016; Oyekale, 2018) without commensurate efforts at exploring associated perception. Scholars of occupational and environmental health such as Ayikoru et al. (2019) and Clouser et al. (2015) advocated further studies on workers perception of personal protective equipment. Perception is considered an important predictor for the use of PPEs (Tinoco et al., 2019), hence the crucial need to improve understanding of the important drivers of farm-workers' behaviour when using protective materials (Rezaei et al., 2019).

There are scant studies that explored the perception of PPEs among farm workers, especially in the banana sector and in the study area. This purpose of this study therefore, was to examine the 
perception of personal protective materials among farm workers in the banana production and processing farms around the lower south coast of Kwa-zulu Natal province. Specifically, the study identified the demographic composition of farm workers in the area, explored their perception of personal protective materials, and established the relationship between demographic characteristics and perception of PPEs. This study contributes to the existing body of knowledge regarding farm-worker safety issues through exploring their perception of personal protective materials.

\section{Applicable theoretical foundation}

Technology acceptance models (TAM) and theory of planned behaviour provide means to measure behavioural intent and perception of any intervention. The theory of planned behaviour (Ajzen, 2011) provides information useful in targeting interventions aimed at locally identified safety and health concerns. Perceived usefulness and perceived ease of use are the two most important determinants for use. The TAM has inevitably been used as a theoretical foundation to explain the intention to use, and a number of studies have extended the use of technology acceptance models into agricultural policy and practice (Zhu et al., 2016). Attitudes and normative issues positively explain farmers' intentions (Zeweld et al., 2017), while perceived usefulness and perceived ease of use are significant predictors of farmers' attitudes. These are similar to the constructs in the health belief model widely used to explain behaviour and attitude in various occupational settings for PPE compliance (Sim et al., 2014; Wright et al., 2019). Similar studies also use additional constructs such as the perceived adequacy of use, following Davis et al. (1989). This construct allows the researcher to capture the occurrence of the desirable intervention in the study (Park et al., 2012). Perceived adequacy of use has been applied to examine the completion of tasks without interruptions occasioned by the use of a technology or equipment.

\section{Materials and methods}

\section{Study area}

The map of the study area is shown in Figure 1 and it is bounded by Umuziwabantu and Umzumbe local municipalities in the north, and share a boundary with the wild coast of Eastern Cape province in the south. The entire eastern section borders the coast overseeing the Atlantic Ocean.

Figure 1. Map showing the study area

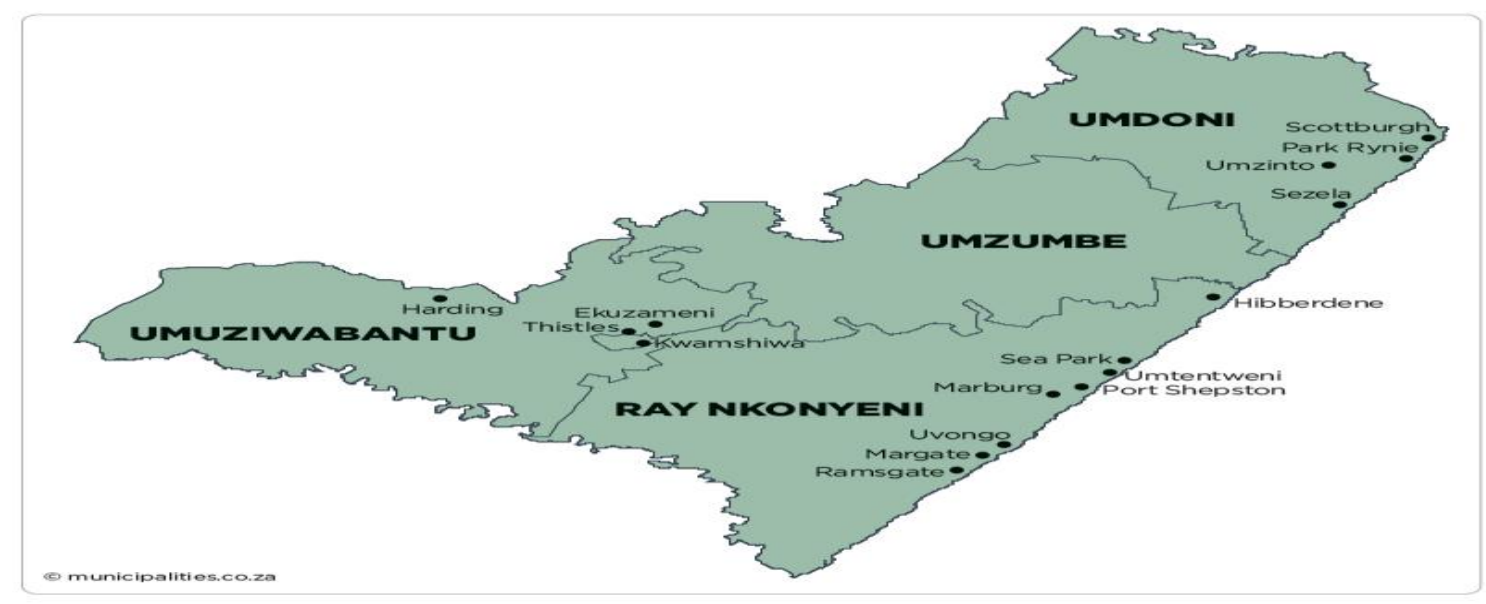


The Ray Nkonyeni local municipality within the coordinates $30.7885^{\circ} \mathrm{S}$ and $30.2513^{\circ} \mathrm{E}$ falls under the Ugu district area with administrative seat located in Port Shepstone and Ezinqoleni. It stretches along the coastal strip from Hibberdene to Port Edward covering $67 \mathrm{~km}$ and about $60 \mathrm{~km}$ into the interior primarily via N2 to Eastern Cape. The Indian Ocean borders the Eastern part of the municipality, while on the Southern part runs Umtamvuna River which is the boundary between Kwa-zulu Natal and the Eastern Cape provinces (ISOCARP, 2016). It is commonly referred to as 'south coast' given its geographical location in relation to the southern coastal part of KwaZulu-Natal. The local economy in the area revolves around tourism, commercial agriculture and some limited manufacturing. The inland of the municipality are mainly rural with farmlands and tribal areas, producing approximately one fifth of the bananas grown in South Africa. The farms are under private ownership while the tribal council areas are largely under the authority of Ingonyama Trust Board (Ray Nkonyeni SDF 2020).

\section{Sampling and sample size}

Banana farms located around Port Edward in the south coast were targeted for the survey between February and June 2020. The choice of these farms was mainly due to strong network coverage which enabled telephonic interview of respondents, the farms were also clustered within a small radius for ease of follow-up during the lockdown period. Ten large scale farms were selected using a lottery method, from among a list of farms provided by the Ugu District extension office of Kwa-zulu Natal Department of Agriculture. Based on willingness to participate in the survey, among other criteria, fifteen farm-workers in each farm were identified for the survey using a snowballing method. Selected participants in the survey had to have a functional phone, worked in the farm for more than one year, and available for follow-up questions when necessary. Three extension workers residing and working within the area were mobilized to conduct the telephonic interviews. A total of 150 respondents were targeted out of an estimated population of 726 farm workers captured in the district department of labour register.

\section{Measurement}

A structured questionnaire was used to collect data from the respondents during the interviews. The instrument contained 15 statements representing measures of two items, perceived usefulness and ease of use were arranged in a single column. These statements were adapted from previous studies so as to ensure the validity of the construct (Chen \& Chengular-Smith, 2015). Both items were measured on a five-point Likert-scale ranging from 'strongly disagree' to 'strongly agree'; and a pre-test was conducted to evaluate the overall interpretability and clarity of the instrument. The internal consistency reliability of the scale was also assessed using Cronbach's alpha coefficient. The values obtained for each item was 0.82 and 0.86 which satisfied the reliability threshold of 0.71 (Nunally \& Bernstein, 1994).

\section{Results and Discussion}

Respondent's characteristics:

In Table 1, the demographic characteristics of respondents from the survey is presented. Male respondents comprise $53 \%$ and females made up $47 \%$. More than half of respondents $(55 \%)$ were aged between $36-55$ years, while $26 \%$ and $15 \%$ of respondents were aged between 19-35 years and more than 56 years respectively. Close to $60 \%$ of the respondents were single as only $41 \%$ in the survey reported being married. The population group consisted of $71 \%$ black Africans, $21 \%$ were coloured and $8 \%$ white. About $20 \%$ of respondents did not have a formal education, 
while $26 \%$ did not complete primary schooling. Though $44 \%$ of respondent completed a primary education, only $7 \%$ attended a high school and $3 \%$ obtained a college or specialized training in agriculture. Furthermore, close to half of respondents (46\%) had between 6-10 years' experience as a farm-worker, $30 \%$ of respondents had experience of between 3-6 years, while $13 \%$ had more than 10 years' experience, and $11 \%$ had less than 3 years' experience working in farms. Survey respondents were predominantly farm labourers making up $72 \%$, those belonging to other skilled classifications such as tractor drivers and machinery operators comprised $21 \%$ of respondents, while $7 \%$ of respondents were farm supervisors.

Table 1: Characteristics of survey respondents

\begin{tabular}{|l|l|c|c|}
\hline \multicolumn{2}{|c|}{ Characteristics } & $\begin{array}{c}\text { Frequency } \\
\text { (n=110) }\end{array}$ & $\%$ \\
\hline Sex & Male & 58 & 53 \\
\hline & Female & 52 & 47 \\
\hline Age & 18 or less & 4 & 4 \\
\hline & $19-35$ & 29 & 26 \\
\hline & $36-55$ & 61 & 55 \\
\hline Marital status & 56 and above & 16 & 15 \\
\hline & Single & 65 & 59 \\
\hline Population group & Married & 45 & 41 \\
\hline & African & 78 & 71 \\
\hline & Coloured & 23 & 21 \\
\hline Education obtained & White & 9 & 8 \\
\hline & None & 22 & 20 \\
\hline & Didn't complete primary school & 29 & 26 \\
\hline & Completed primary school & 47 & 44 \\
\hline & High school & 8 & 7 \\
\hline Number of years as farm-worker & Other (agric. college or training) & 4 & 3 \\
\hline & Less than 3 years & 12 & 11 \\
\hline & 3 - 6 years & 33 & 30 \\
\hline & $6-10$ years & 51 & 46 \\
\hline & More than 10 years & 14 & 13 \\
\hline & Farm labourer & 79 & 72 \\
\hline & Supervisor & 23 & 21 \\
\hline & Other skilled & & 7 \\
\hline
\end{tabular}

Source: Telephonic survey 2020

The finding shows that on average, farm-workers in the area were single black males aged between 36-55years, had no more than a primary education with work experience of between 610 years and generally worked as unskilled farm-hands.

\section{Perception of respondents:}

To determine the perception of survey respondents to the use of personal protective equipment, various statements related to perception were identified. These statements were aligned to the perception of usefulness (PU) and ease of use (PEU) constructs, which have been validated in to 
strongly affect perception. Respondents were requested to indicate their level of agreement with the statements, and ranged from strongly agree, agree, neutral, disagree to strongly disagree. Table 2 shows the response received from the survey. The responses for strongly agree (SA) and agree (A) were counted as agreed, as well as those for strongly disagree (SD) and disagree (D) were collapsed and counted as disagreed.

Table 2: Perception scale with statements representing identified constructs.

\begin{tabular}{|c|c|c|c|c|c|c|c|c|}
\hline & Statements related to perception of PPEs & $\begin{array}{l}\text { SA } \\
(\%)\end{array}$ & $\begin{array}{c}\text { A } \\
(\%)\end{array}$ & $\begin{array}{c}N \\
(\%) \\
\end{array}$ & $\begin{array}{c}D \\
(\%)\end{array}$ & $\begin{array}{l}\text { SD } \\
(\%)\end{array}$ & Mean & $\begin{array}{l}\text { Std. } \\
\text { Dev. }\end{array}$ \\
\hline \multirow[t]{10}{*}{ PU } & $\begin{array}{l}\text { PPEs are vital component of my dressing for } \\
\text { farm work. }\end{array}$ & 63.7 & 28.3 & 1.2 & 6.8 & 0.0 & 1.51 & 0.83 \\
\hline & $\begin{array}{l}\text { I find it very necessary to use protective } \\
\text { equipment. }\end{array}$ & 66.3 & 27.0 & 2.4 & 4.4 & 0.0 & 1.45 & 0.75 \\
\hline & $\begin{array}{l}\text { I don't need to be reminded to use protective } \\
\text { equipment. }\end{array}$ & 57.1 & 25.4 & 0.0 & 13.9 & 3.6 & 1.77 & 1.12 \\
\hline & Every farm worker must wear protective items. & 54.2 & 28.7 & 3.2 & 13.5 & 0.4 & 1.77 & 1.05 \\
\hline & $\begin{array}{l}\text { All items of protection must be worn at all } \\
\text { times. }\end{array}$ & 43.5 & 36.7 & 0.4 & 11.3 & 8.1 & 1.88 & 0.20 \\
\hline & $\begin{array}{l}\text { My safety boots protects me against foot } \\
\text { injuries at work. }\end{array}$ & 50.5 & 29.4 & 4.7 & 15.1 & 0.4 & 2.34 & 1.29 \\
\hline & $\begin{array}{l}\text { Respiratory (face) masks protects me against } \\
\text { lung disease. }\end{array}$ & 53.3 & 40.1 & 1.2 & 5.5 & 0.0 & 1.89 & 1.03 \\
\hline & $\begin{array}{l}\text { The overalls I wear keep chemical spills away } \\
\text { from my body. }\end{array}$ & 35.7 & 24.2 & 10.8 & 13.9 & 5.4 & 1.99 & 1.0 \\
\hline & $\begin{array}{l}\text { My protective gloves help keep my hands safe } \\
\text { from scars. }\end{array}$ & 44.0 & 32.3 & 5.6 & 17.3 & 0.8 & 1.98 & 1.13 \\
\hline & Construct mean & & & & & & 1.84 & 0.93 \\
\hline \multirow[t]{7}{*}{ PEU } & $\begin{array}{l}\text { Farm workers require training to use protective } \\
\text { equipment. }\end{array}$ & 0.4 & 7.9 & 14.3 & 71.4 & 6.0 & 3.75 & 0.70 \\
\hline & $\begin{array}{l}\text { Employers must take action against those not } \\
\text { using PPEs. }\end{array}$ & 9.6 & 8.4 & 14.3 & 59.0 & 8.8 & 3.49 & 1.08 \\
\hline & $\begin{array}{l}\text { Many of my colleagues do not use protective } \\
\text { wears correctly. }\end{array}$ & 0.8 & 6.0 & 24.2 & 52.4 & 16.7 & 3.78 & 0.82 \\
\hline & $\begin{array}{l}\text { Using protective equipment affects the way I } \\
\text { normally work. }\end{array}$ & 0.0 & 8.8 & 11.6 & 55.8 & 23.9 & 3.95 & 0.84 \\
\hline & $\begin{array}{l}\text { I find it cumbersome to use some of the } \\
\text { protective equipment. }\end{array}$ & 2.4 & 0.4 & 2.4 & 36.8 & 58.0 & 4.48 & 0.78 \\
\hline & $\begin{array}{l}\text { Protective materials are not comfortable to } \\
\text { wear for work. }\end{array}$ & 2.0 & 8.7 & 1.3 & 25.7 & 62.3 & 2.63 & 1.33 \\
\hline & Construct mean & & & & & & 3.68 & 0.92 \\
\hline
\end{tabular}


Table 3 shows that responses were aligned towards the positive statements related to perception of usefulness. Also the responses indicate a strong disagreement for the negative statements related to perceived ease of use. About $91 \%$ of respondents agreed that protective equipment were vital components of dressing for farm work, $93 \%$ found it necessary to use protective equipment, $83 \%$ agreed that all farm worker must wear protective items, and $80 \%$ were in agreement that all protective materials must be worn at all times while working in the farm. For specific protective items, $80 \%$ of respondents agreed that safety boots protected them against foot injuries, 94\% affirmed that face masks provided protection against respiratory infections, $60 \%$ agreed that overalls protected them from chemical spills, with $76 \%$ agreeing that hand gloves offered protection against scars. For perceived ease of use, $85 \%$ of respondents disagreed with the statement suggesting that workers require training to use PPEs, $77 \%$ disagreed that their colleagues do not use protective wears correctly, $67 \%$ did not agree that using protective clothing affected their work flow, 95\% did not find it cumbersome to use personal protective materials while $88 \%$ of respondent disagreed that protective materials were uncomfortable to wear while working. In general, $83 \%$ of survey respondents agreed, $3 \%$ were undecided while $14 \%$ disagreed with the perceived usefulness of PPEs. Furthermore, $79 \%$ of respondents agreed, $11 \%$ were undecided and $9 \%$ disagreed with the perceived ease of using PPEs.

Impact of Perception constructs:

The degree of association with perception represented by the significance of the two constructs, was also examined as shown in Table 3.

Table 3: Impact of various constructs on perception of farm-workers

\begin{tabular}{|l|l|l|l|l|l|l|}
\hline \multicolumn{1}{|c|}{ Construct } & Total $(\mathbf{n})$ & \multicolumn{1}{|c|}{ Mean } & $\begin{array}{l}\text { Std. } \\
\text { Dev. }\end{array}$ & t-value & \multicolumn{1}{c|}{ df } & Sig. $^{*}$ \\
\hline Perceived usefulness (PU) & 110 & 1.84 & 0.933 & 46.70 & 102 & 0.000 \\
\hline $\begin{array}{l}\text { Perceived ease of use } \\
\text { (PEU) }\end{array}$ & 110 & 3.68 & 0.924 & 42.13 & 102 & 0.000 \\
\hline
\end{tabular}

*Significant at $1 \%$

Table 3 indicates that the p-values $(0.000)$ for the constructs were less than 0.01 level of significance, showing that perceived usefulness and ease of use strongly impacted the perception of PPEs among the surveyed farm workers. This underlies the important role of these two perception constructs, which Rezaei et al. (2019) described as antecedents of farmers' PPE behaviour.

Relationship between perception constructs and personal characteristics:

Personal characteristics play a role in determining perceptions, and the categories making up these characteristics were used to check for differences in both perception of usefulness, and perceived ease of use among respondents. The relationship between these perception constructs and the personal characteristics of the study respondents is shown in Table 4. 
Table 4: Perception constructs and personal characteristics of respondents

\begin{tabular}{|c|c|c|c|c|c|c|}
\hline Variable & Category & $\begin{array}{c}\mathrm{PU} \\
\text { mean }\end{array}$ & $\begin{array}{l}\text { PEU } \\
\text { mean }\end{array}$ & $\begin{array}{l}\text { Std } \\
\text { Dev }\end{array}$ & $\mathbf{t}$ & p-value \\
\hline \multirow[t]{2}{*}{ Sex } & Male & 1.79 & 3.77 & 0.89 & \multirow{2}{*}{2.705} & \multirow{2}{*}{$0.012^{*}$} \\
\hline & Female & 1.87 & 3.68 & 0.91 & & \\
\hline \multirow[t]{4}{*}{ Age } & 18 and less & 1.88 & 3.25 & 0.94 & \multirow{4}{*}{2.104} & \multirow{4}{*}{0.057} \\
\hline & $19-35$ & 1.64 & 3.94 & 0.87 & & \\
\hline & $36-55$ & 1.69 & 3.66 & 0.78 & & \\
\hline & 56 and above & 1.98 & 3.43 & 0.96 & & \\
\hline \multirow[t]{2}{*}{ Marital status } & Single & 1.80 & 3.78 & 0.88 & \multirow{2}{*}{2.784} & \multirow{2}{*}{$0.029^{*}$} \\
\hline & Married & 1.90 & 3.85 & 0.87 & & \\
\hline \multirow[t]{3}{*}{$\begin{array}{l}\text { Population } \\
\text { Group }\end{array}$} & African & 1.91 & 3.58 & 0.77 & \multirow{3}{*}{2.028} & \multirow{3}{*}{0.160} \\
\hline & Coloured & 1.82 & 3.61 & 0.81 & & \\
\hline & White & 1.65 & 3.89 & 0.90 & & \\
\hline \multirow[t]{5}{*}{ Education } & None & 1.66 & 3.52 & 0.91 & \multirow{5}{*}{2.163} & \multirow{5}{*}{$0.035^{*}$} \\
\hline & $\begin{array}{c}\text { Didn't complete primary } \\
\text { school }\end{array}$ & 1.69 & 3.55 & 0.89 & & \\
\hline & $\begin{array}{c}\text { Completed primary } \\
\text { school }\end{array}$ & 1.75 & 3.59 & 0.90 & & \\
\hline & High school & 1.86 & 3.90 & 0.88 & & \\
\hline & $\begin{array}{c}\text { Other (agric. college or } \\
\text { training) }\end{array}$ & 1.92 & 3.94 & 0.94 & & \\
\hline \multirow[t]{4}{*}{$\begin{array}{c}\text { Farm } \\
\text { experience } \\
\end{array}$} & Less than 3 years & 1.45 & 3.45 & 0.89 & \multirow{4}{*}{2.659} & \multirow{4}{*}{$0.008^{*}$} \\
\hline & $3-6$ years & 1.56 & 3.53 & 0.92 & & \\
\hline & $6-10$ years & 1.87 & 3.67 & 0.98 & & \\
\hline & More than 10 years & 1.89 & 3.69 & 0.96 & & \\
\hline \multirow[t]{3}{*}{$\begin{array}{c}\text { Work } \\
\text { classification }\end{array}$} & Farm labourer & 1.86 & 3.67 & 0.96 & \multirow{3}{*}{2.076} & \multirow{3}{*}{0.203} \\
\hline & Supervisor & 1.89 & 3.68 & 0.85 & & \\
\hline & Other skilled & 1.78 & 3.66 & 0.82 & & \\
\hline
\end{tabular}

Table 4 shows that gender of respondents was significant to the perception of personal protective materials among surveyed farm-workers $(p=0.012)$. While female farm-workers had a higher mean value for perceived usefulness, the mean value for perceived ease of use was lower than among male farm-workers. This is consistent with the finding by Abukelaif (2019) and Tinoco et al. (2019), wherein they reported that women had a higher risk perception and concluded that gender had a significant effect on the effective use of PPEs. It also accounts for the difference in PEU values between gender groups in this study. Kisaka-Lwayo and Obi (2012) opined that 
perception of risk differs between gender groups. Aluko et al. (2016) and Nkomo et al. (2018) also reported that gender was associated with higher attitudes to occupational hazards and safety practices, though Aluko et al. (2016) found no association between gender and perception. This position agrees with Chaswa et al. (2020) where they reported that gender had no effect on risk perception among construction workers. Wagner et al. (2013) admitted a lack of personal protective materials specifically designed for women, or those made taking gender into consideration. Across a much larger spectrum of physically engaging work, such as in agriculture and construction, recommendations have been made to take into account the differing body characteristics and needs based on gender.

Age was not found to be significant $(p=0.057)$ in the perception constructs among farm-workers surveyed. Langley et al. (2018) suggested from their study, that using age as a predictor of usefulness and ease of use had limited practical significance, and is consistent with the review results from Duong et al. (2019) showing mixed findings between the age of farmers and risk perception. Hashemi et al. (2012) also found no effect of age on safety competency measures due to the impact of mediating variables. These are in line with the report by Abukhelaif (2019) that age was not associated with the use of protective materials. However, Okoffo et al. (2016) reported the influence of age on the decision of farmers in using PPEs, while Damalas et al. (2019) and Obarhoro et al. (2020) concluded that there was significant relationship between age groups and use of PPEs. From their study, Damalas and Abdollahzadeh (2016) reported that age had a significant negative influence on use of PPEs. The diverse categories for age, including the different variables measured using dissimilar approaches, might account for these findings.

The marital status of respondents in the study was found to be significant $(p=0.029)$ to their perception of using PPEs. Married respondents showed higher mean values for perceived usefulness and ease of use than respondents who were single. The finding agrees with Aluko et al. (2016) who reported that marital status was associated with strong perception of occupational hazards and safety practices. These findings are consistent with the report by Damalas et al. (2019) suggesting that the effect of marital status was significant for importance of personal safety. Abdolahzadeh et al. (2012) found that perception of patient safety culture among nurses was significantly correlated with marital status, and is consistent with the finding by Cvetkovic (2019) showing that marital status was an important predictor of risk perception. Kambris et al. (2019) also reported a significant relationship between cumulative perceptions of exposure to hazards and marital status.

Different ethnic or racial groups classified as African, coloured or white abound within the study area, and this attribute of the surveyed farm-workers were used to compare possible differences in their perception of personal protective materials. The study found no significant association between group identity and perception of PPEs $(p=0.160)$. However, mean values for PU $(x=1.91)$ was higher among African workers who comprise most of the unskilled farm-hands, while mean values for PEU ( $\mathrm{x}=3.89)$ was higher among white farm-workers usually predominant in supervisory or skilled positions in the farms. The finding is not consistent with the observation by Aluko et al. (2016), that ethnicity influenced perception of occupational hazards and safety practices. According to Han et al. (2018) certain sub-group factors play a role in safety issues, and these additional factors such as level of education and work category, could explain the differences in mean values for PU and PEU found in this study.

Education was found to be significantly associated with perception of personal protective materials among respondents in the survey $(p=0.039)$. Respondents with higher levels of 
education or training had consistently higher mean values for perceived usefulness and ease of use. Those who attained post-high school education or training scored a mean PU and PEU values of $x=1.92$ and $x=3.94$ respectively, compared to, those with only a primary school education with mean PU and PEU values of $x=1.75$ and $x=3.59$ respectively, and respondents without an education with a mean PU value of $x=1.66$ and PEU value of $x=3.52$. The significant role of education towards safety attitudes and perception is corroborated in the literature. Jallow et al. (2017) reported that educated farmers were significantly more likely to use PPEs, when compared to those with limited or no formal education. These findings are consistent with Okoffo et al. (2016) regarding the influence that level of education had on farmers decisions related to PPEs, and Damalas et al. (2019) who identified education as an important predictor of perceived importance of safety issues.

Farm work experience was found to be significant to the perception of personal protective materials among respondents, as the mean values for both perceived usefulness and ease of use were higher with increasing number of years. Kassem and Alotaibi (2020) also reported a significant association between farming experience and risk perception. The perception of risk affects behaviour and possible adoption of specific risk-management strategy such as use of PPEs. Denton et al. (2018) linked perception of safety to number of years spent on the job, and agreed with Cafarro et al. (2018) where work experience was a mediating factor in decreasing work accidents among agricultural machinery operators, which is consistent with the findings of this study. However, Chaswa et al. (2020) concluded from their study that the length of work experience had no effect on perception of risk among construction workers.

Work classification was not significant to farm-workers perception of personal protective materials in this study. The mean values for perception of usefulness and perceived ease of use among the sub-groups did not show any effect. This finding is consistent with Chaswa et al. (2020) where the professional category or skill classification was not significant to perception of risk. However, Portell et al. (2014), reported work classification to be a significant predictor of risk categories among health-care workers.

\section{Conclusion}

The study used two constructs namely perceived usefulness and perceived ease of use to explore the perception of personal protective materials among farm-workers. These constructs were determined to strongly align with perception. It was found that more than half of farm-workers in the area were black males, more than 35years but less than 56 years, mostly single with no more than a basic primary education and employed as farm labourers. Majority of farm-workers in the study perceived protective materials to be useful, with a positive perception of perceived ease of use reported. There was a strong perception of usefulness for specific protective materials, such as safety boots, coveralls, hand gloves and mask reported. Many were in agreement that these materials did not encumber their ability to work smoothly. The gender, marital status, education and farm-work experience were significant; while age, population group and work classification were not significant in determining the perceived usefulness or perceived ease of use for personal protective materials among the study respondents.

Perceived usefulness and perceived ease of use helped to determine perception among farmworkers in the survey, though additional factors such as availability, compliance checks, workplace policies and training are key in explaining related behaviours. The study contributes in highlighting possible differences in how individual farm-workers perceive personal protective 
materials, which invariably determine how they respond in daily actions to personal safety measures.

\section{References}

Abdolazadeh, F., Zamanzadeh, V. and Boroumand, A. (2012). Studying the Relationship between Individual and Organizational Factors and Nurses' Perception of Patient Safety Culture. Journal of Caring Sciences, 1(4): 215-222.

Abukhelaif, A.E. (2019). Personal Protective Equipment Knowledge and Practices among Nurses Working at Al-Baha King Fahad Hospital, Saudi Arabia. Journal of Healthcare Communications, 4(1): DOI: 10.4172/2472-1654.100152.

Afrad, M.S., Barau, A.A., Haque, M.E. and Habibullah, M. (2020). Farmers' Use of Personal Protection Equipment in Jeshore and Rajshahi Districts of Bangladesh. Journal of Education, Society and Behavioural Science, 33(3): 1-14.

Aguwa, E.N., Arinze-Onyia, S.U. and Ndu, A. (2016). Use of Personal Protective Equipment among Health Workers in a Tertiary Health Institution, South East Nigeria: Pre-Ebola Period. International Journal of Health Sciences \& Research, 6(8): 12-18.

Ajzen, I. (2011). The theory of planned behaviour: Reactions and reflections. Psychology and Health, 26(9): 1113-27.

Aluko, O.O., Adebayo, A.E., Adebisi, T.F., Ewegbemi, M.K., Abidoye, A.T. and Popoola, B.K. (2016). Knowledge, attitudes and perceptions of occupational hazards and safety practices in Nigerian healthcare workers. BMC Research Notes, 9:71 DOI 10.1186/s13104-016-1880-2.

Ayikoru, M., Ddamulira, C. and Mutekanga, D.R. (2019). Determinants of Employee use of Personal Protective Equipment, the Case of Spedag Interfreight Uganda Limited, Kampala. Journal of Environmental Science and Public Health, 3: 419-434.

Baksh, K., Ganpat, W. and Narine, L. (2015). Farmers' knowledge, attitudes and perceptions of occupational health and safety hazards in Trinidad, West Indies and implications for the Agriculture sector. Journal of Agricultural Extension and Rural Development, 7(7): 221-228.

Barrientos, S. and Visser, M. (2012). South African Horticulture: Opportunities and Challenges for economic and social upgrading in value chains. Working Paper 12. University of Manchester and University of Cape Town.

Botes, J., van der Westhuizen, M. and Alpaslan, N. (2014). Informing employee assistance programmes for farm workers: An exploration of the social circumstances and needs of farm workers in the Koup. Social Work, 50(1): 38-58. DOI: http://dx.doi.org/10.15270/50-1-15.

Business and Human Rights Resource Centre. August 2020. Workers in agricultural supply chains among groups most at risk of COVID-19 infection. Retrieved $12^{\text {th }}$ September 2020 from https://www.businesshumanrights.org/en/latest-news/workers-in-agricultural-supply-chains-among-groups-most-at-risk-ofcovid-19-infection/

Cafarro, F., Roccato, M., Cremasco, M.M. and Cavallo, E. (2018). Falls from agricultural machinery: Risk factors related to work experience, worked hours, and operators' behaviour. Human Factors, 60(1): 20-30.

Chaswa, E.N., Kosamu, I.B., Kumwenda, S. and Utembe, W. (2020). Risk Perception and Its Influencing Factors among Construction Workers in Malawi. Safety, 6, 33; doi:10.3390/safety6020033. 
Chen, Y.H., Chengalur-Smith, I. (2015). Factors influencing students' use of a library Web portal: Applying course-integrated information literacy instruction as an intervention. The Internet and Higher Education, 26, 42-55.

Clouser, J.M., Swamberg, J.E. and Bundy, H. (2015). Keeping workers safe: Does provision of personal protective equipment match supervisor risk perceptions? American Journal of Industrial Medicine, 58:886896.

Coman, M.A., Marcu, A., Chereches, R.M., Leppala, J. and Broucke, S. (2020). Educational interventions to improve safety and health literacy among agricultural workers: A systematic review. International Journal of Environmental Research and Public Health, 2020, 17, 1114; doi:10.3390/ijerph17031114

Cvetkovic, V.M. (2019). Risk Perception of Building Fires in Belgrade. International Journal of Disaster risk Management, 1(1): 81-91.

Damalas, C.A., Koutroubas, S.D. and Abdollahzadeh, G. (2019). Drivers of Personal Safety in Agriculture: A Case Study with Pesticide Operators. Agriculture 2019, 9, 34; doi:10.3390/agriculture9020034.

Damalas, C.A. and Abdollahzadeh, G. (2016). Farmers' use of personal protective equipment during handling of plant protection products: Determinants of implementation. Science of the Total Environment (in-press); http://dx.doi.org/10/1016/..scitotenv.2016.07.042.

Davis, F. D., Bagozzi, R. P. and Warshaw, P. R. (1989). User acceptance of computer technology: A comparison of two theoretical models. Management Science 35, 982-1002.

Denton, M., Zeytinoglu, I.U., Brookman, C., Davies, S. and Boucher, P. (2018). Personal support workers' perception of safety in a changing world of work. Safety in Health, 4: 2. https://doi.org/10.1186/s40886-0180069-x.

Duong, T.T., Brewer, T., Luck, J. and Zander, K. (2019). A Global Review of Farmers' Perceptions of Agricultural Risks and Risk Management Strategies. Agriculture, 9, 10; doi:10.3390/agriculture9010010.

ECDC (2020). COVID-19 clusters and outbreaks in occupational settings in the EU/EEA and the UK. Technical Report. European Centre for Disease Prevention and Control, Stockholm.

Han, Y., Feng, Z., Zhang, J., Jin, R. and Aboagye-Nimo, E. (2018). An Empirical Study of Employees' Safety Perceptions of Site Hazard and Accident Scenes. Journal of Construction Engineering and Management, 145(1), DOI: 10.1061/(ASCE)CO.1943-7862.0001590.

Hashemi, S.M., Hosseini, S.M., Hashemi, M.K. (2012). Farmers' perceptions of safe use of pesticides: determinants and training needs. International Archives on Occupational and Environmental Health, 85:5766.

Herrick, C. (2012). The political ecology of alcohol as 'disaster' in South Africa's Western Cape. Geoforum 43, 1045-1056.

Human Rights Watch (2011). Ripe with abuse: Human rights conditions in South Africa's fruit and wine industry. New York: Human Rights Watch.

ISOCARP (2016). Ray Nkonyeni Municipality. Retrieved $15^{\text {th }}$ September 2020 from https://isocarp.org/app/uploads/2016/03/Technical-Workshop-5-Ray-Nkonyeni-Municipality-PreviouslyHCM.pdf.

Jallow, M.F., Awadh, D.G., Albaho, M.S., Devi, V.Y. and Thomas, B.M. (2017). Pesticide Knowledge and Safety Practices among Farm Workers in Kuwait: Results of a Survey. Int. J. Environ. Res. Public Health 2017, 14, 340 . 
Kambris, M.E., Khan, S. and Al Falasi, S.N. (2019). Perceptions of Health and Safety among Workers in the Automotive Repair Industry in Dubai (United Arab Emirates): A Cross-sectional Exploratory Study. Journal of Ecophysiology and Occupational Health, 19(3\&4): 126 - 135.

Kassem, H.S., Alotaibi, B.A. (2020). Do farmers perceive risks of fraudulent pesticides? Evidence from Saudi Arabia. PLoS ONE 15(9): e0239298. https://doi.org/10.1371/journal. pone.0239298.

Kisaka-Lwayo, M. and Obi, A. (2012). Risk perceptions and management strategies by smallholder farmers in KwaZulu-Natal Province, South Africa. International Journal of Agricultural Management, 1: 28-39.

Klaas, N.E., Thupayagale-Tshweneagea, G., Makau, T.P. (2018). The role of gender in the spread of HIV and Aids among farmworkers in South Africa. African Journal of Primary Health Care and Family Medicine, 10(1): 1668. Doi:10.4102/phcfm.v10i1.1668.

Landman, C. (2011). A public theology for 'intimate' spaces. International Journal of Public Theology, 5: 63-77.

Langley, G.C., Tummons, J.D. and Kitchel, T. (2018). Influences on the Perceived Comfort and Training Level of Personal Protective Equipment in the Missouri High School Agricultural Mechanics Laboratory. Journal of Agricultural Education, 59(4), 20-35.

London, L. (2003). Human Rights, Environmental Justice, and the Health of Farm Workers in South Africa. International Journal of Occupational and Environmental Health, 9(1):59-68.

Merisalu, E., Leppala, J., Jakob, M. and Rautiainen, R. (2019). Variation in Eurostat and national statistics of accidents in agriculture. Agronomic Research, 2019, 17, 1969-83.

Meyer B., Flocks, J., Monaghan, P. The role of employers and supervisors in promoting pesticide safety behavior among Florida farmworkers. Am. J. Ind. Med. 2010, 53, 814-824.

National Geographic (2020). Science: Coronavirus coverage. Farmworkers risk coronavirus infection to keep the US fed. Retrieved from https://www.nationalgeographic.com/science/2020/04/farmworkers-riskcoronavirus-infection-keep-us-fed/

Nkomo, H., Niranjan, I. and Reddy, P. (2018). Effectiveness of health and safety training in reducing occupational injuries among harvesting forestry contractors in Kwazulu-Natal. Workplace Health and Safety, 66(10): 499-506.

Nunally, J. C., Bernstein, I. H. (1994). Psychometric Theory. New York: McGraww-Hill.

Obarhoro, O.I., Nwufo, C.R., Nworu, B., Ibe, S.N.I., Iwuala, C.C., Ede, A., Ebirim, C.I.C. et al. (2020). Compliance in the Use of Personal Protective Equipment by Welders in Delta State, Nigeria. International Journal of Research and Review, 7(1): 21-26.

Okoffo, E.D., Mensah, M. and Fosu-Mensah, B.Y. (2016). Pesticides exposure and the use of personal protective equipment by cocoa farmers in Ghana. Environmental Systems Research, 5:17 DOI 10.1186/s40068-016-0068-z.

Oyekale, A.S. (2018). Cocoa Farmers' Compliance with Safety Precautions in Spraying Agrochemicals and Use of Personal Protective Equipment (PPE) in Cameroon. International Journal of Environmental Research and Public Health, 15, 327; doi:10.3390/ijerph15020327

Park, Y., Son, H. and Kim, C. (2012). Investing the determinants of construction professional acceptance of web-based training: An extension of the technology acceptance model. Automation in Construction, 22, 377-386. 
Portell, M., Gil, M.R., Losilla, M.J. Vives, J. (2014). Characterizing occupational risk perception: The case of biological, ergonomic and organizational hazards in Spanish healthcare workers. Spanish Journal of Psychology, 17: 1-12.

Ramos, A.K., Fuentes, A. and Trinidad, N. (2016). Perception of Job-Related Risk, Training, and Use of Personal Protective Equipment (PPE) among Latino Immigrant Hog CAFO Workers in Missouri: A Pilot Study. Safety 2016, 2, 25; doi:10.3390/safety2040025.

Ray Nkonyeni, Spatial Development Framework Review 2020-21. Retrieved 23 ${ }^{\text {rd }}$ September 2020 from http://www.rnm.gov.za/Departments/Economic Development planning/SDF/Ray\%20Nkonyeni\%20Final\%20SDF\%20Review \%2003\%20March\%202020.pdf

Rezaei, R., Seidi, M. and Karbasioun M. (2019). Pesticide exposure reduction: Extending the theory of planned behavior to understand Iranian farmers' intention to apply personal protective equipment. Safety Science, 120: 527-537.

Republic of South Africa. (2020). Essential services covid-19. Retrieved $10^{\text {th }}$ September from https://www.gov.za/covid-19/companies-and-employees/essential-services-coronavirus-covid-19.

Sim, S.W., Moey, K.S. and Tan, N.C. (2014). The use of facemasks to prevent respiratory infection: A literature review in the context of the Health Belief Model. Singapore Medical Journal, 55:160-167.

Summers A. (2020). Spain imposes regional lockdowns amid resurgence of COVID-19. Retrieved 25 July 2020 from https://www.wsws.org/en/articles/2020/07/10/spai-j10.html.

Tinoco, H.C., Lima, G.B., Sant'Anna, A.P., Gomes, C.F. and dos Santos, J.A. (2019). Risk perception in the use of personal protective equipment against noise-induce hearing loss. Gestão \& Produção, 26(1), e1611. https://doi.org/10.1590/0104-530X1611-19.

Visser, M. and Ferrer, S. (2015). Farm worker's living and working conditions in South Africa: Key trends, emergent issues, and underlying and structural problems. Report commissioned by the International Labour Organisation (ILO). February 2015.

Wagner, H., Kim, A.J. and Gordon, L. (2013). Relationship between Personal Protective Equipment, SelfEfficacy, and Job Satisfaction of Women in the Building Trades. Journal of Construction Engineering and Management, DOI:10.1061/(ASCE)CO.1943-7862.0000739.

Wright, T., Adhikari, A., Yin, J., Vogel, R., Smallwood, S. and Shah, G. (2019). Issue of Compliance with Use of Personal Protective Equipment among Wastewater Workers across the Southeast Region of the United States. International Journal of Environmental Research and Public Health, 16(11). doi: $10.3390 /$ ijerph16112009.

Zeweld, W., Hoylenbroeck, G., Tesfay, G. and Speelman, S. (2017). Smallholder farmers' behavioural intentions towards sustainable agricultural practices. Journal of Environmental Management, 187(1): 7181.

Zhu, H., You, H., Kan, L. and Guan, Z. (2016). Analysis of Farmers' Intention to Accept Wetland Compensation Policy: China Farmers' Perspective. 